\title{
Insights Into the Physiology of C-peptide
}

\section{Daniela VEJRAZKOVA ${ }^{1}$, Marketa VANKOVA ${ }^{1}$, Petra LUKASOVA ${ }^{1}$, Josef VCELAK ${ }^{1}$, Bela BENDLOVA ${ }^{1}$}

${ }^{1}$ Institute of Endocrinology, Prague, Czech Republic

Received March 23, 2020

Accepted May 18, 2020

\section{Summary}

Current knowledge suggests a complex role of C-peptide in human physiology, but its mechanism of action is only partially understood. The effects of C-peptide appear to be variable depending on the target tissue, physiological environment, its combination with other bioactive molecules such as insulin, or depending on its concentration. It is apparent that C-peptide has therapeutic potential for the treatment of vascular and nervous damage caused by type 1 or late type 2 diabetes mellitus. The question remains whether the effect is mediated by the receptor, the existence of which is still uncertain, or whether an alternative non-receptor-mediated mechanism is responsible. The Institute of Endocrinology in Prague has been paying much attention to the issue of C-peptide and its metabolic effect since the 1980s. The RIA methodology of human C-peptide determination was introduced here and transferred to commercial production. By long-term monitoring of C-peptide oGTT-derived indices, the Institute has contributed to elucidating the pathophysiology of glucose tolerance disorders. This review summarizes the current knowledge of C-peptide physiology and highlights the contributions of the Institute of Endocrinology to this issue.

\section{Key words}

C-peptide • Insulin • Diabetes mellitus • Therapy • Diabetes complications

\section{Corresponding author}

D. Vejrazkova, Department of Molecular Endocrinology, Institute of Endocrinology, Narodni 8, 11694 Prague 1, Czech Republic. Fax: +420 224905 325. E-mail: dvejrazkova@endo.cz

\section{Basic framework}

Connecting peptide (C-peptide), a cleavage product of proinsulin, is a small linear molecule composed of 31 aminoacids. In the Golgi complex of pancreatic beta cells, C-peptide is removed from proinsulin, forming the insulin molecule. Both insulin and $\mathrm{C}$-peptide are then stored in an equimolar ratio in the secretory vesicles of the beta cells until stimulation by elevated glycemia. After their release to portal circulation, insulin and C-peptide differ in their kinetics: insulin has a half-life of about $3 \mathrm{~min}, \mathrm{C}$-peptide about $30 \mathrm{~min}$. Its stability, along with the fact that C-peptide escapes first-pass metabolism by the liver, allows the use of C-peptide as a reliable marker of beta cell function in clinical practice.

\section{The intrinsic biological activity of $\mathrm{C}$-peptide and therapeutic potential}

For decades, C-peptide was thought to be a biologically inert by-product of insulin processing. However, recent studies have shown that C-peptide is a bioactive molecule with remarkable effects on various cell types and tissues. Its action appears to be ambiguous depending on the target tissue, physiological environment, its combination with other bioactive molecules such as insulin (Richards et al. 2014), or depending on its concentration. Some trials have demonstrated that C-peptide is associated with macrovascular complications when its concentrations are high and with microvascular complications when its concentrations are low. For example, insulin resistant 
patients with early type 2 diabetes mellitus (T2DM) have high serum levels of C-peptide. Elevated C-peptide contributes to the atherosclerotic process in these patients (Wang et al. 2015) and higher C-peptide has also been shown to be associated with cardiovascular morbidity in the insulin resistant non-diabetic population (Cabrera et al. 2015). On the other hand, in type 1 diabetes mellitus (T1DM) patients with serious defects in their own C-peptide production, its replacement exerts a beneficial influence on microvascular complications (Wahren 2017) and nerve function (Ekberg et al. 2007). Also, residual C-peptide production in T1DM patients correlates negatively with $\mathrm{HbA}_{1 \mathrm{c}}$ levels, daily insulin dose, the incidence of severe hypoglycemia and with the severity of microvascular dysfunction leading to neuropathy, suggesting C-peptide even at low picomolar levels may be essential for the long-term maintenance of endothelial function (Lachin et al. 2014). In vitro, C-peptide has been shown to reduce oxidative stress by inhibiting the formation of endothelial cell reactive oxygen species under hyperglycemic or stressful conditions (Bhatt et al. 2013a, Luppi and Drain 2017), contributing to anti-apoptotic and anti-inflammatory responses. C-peptide also inhibits the expression of hyperglycemia-induced adhesion molecules, thus reducing leukocyte adhesion to endothelial cell walls and preventing atherosclerotic plaque formation (Yosten et al. 2014). In addition, beta cell transplantation resulting in the restoration of endogenous insulin and C-peptide concentrations leads to the amelioration of structural and functional peripheral nerve and kidney damage induced by diabetes (Fiorina et al. 2003, Navarro et al. 1997).

\section{Receptor or non-receptor-mediated signaling?}

These findings suggest a complex role of C-peptide in human physiology, although the mechanism behind this role is only partially understood. The question remains whether the effect is mediated by the receptor, the existence of which is still uncertain, or whether alternative non-receptor-mediated mechanisms are responsible. Multiple studies have demonstrated that C-peptide binds specifically to many cell types such as fibroblasts, kidney tubules, and endothelial cells (Pramanik et al. 2001, Henriksson et al. 2001, Yosten and Kolar 2015). C-peptide has been shown to activate various intracellular signaling pathways, such as phospholipase C (PLC), mitogen-activated protein kinase (MAPK), phosphoinositide-3-kinase/protein kinase B
(PI3K/AKT), AMP-activated protein kinase (AMPK), nuclear factor kappa B (NF- $\mathrm{kB})$, protein kinase A (PKA) and protein kinase $\mathrm{C}(\mathrm{PKC})$. These pathways initiate endothelial nitric oxide synthase (eNOS) and the activity of $\mathrm{Na}^{+}$or $\mathrm{K}^{+}$ATPses and thus trigger the expression of many transcription factors (Kitamura 2001, Richards 2015, Bhatt et al. 2013b, Haidet et al. 2012, Zhong et al. 2004, Zhong et al. 2005). Involvement in the aforementioned signaling cascades, together with the high pertussis toxin-sensitivity of C-peptide action, would imply an interaction of C-peptide with a G-proteincoupled receptor (GPR) or receptor complex on the surface of cell membranes. Specifically, GPR146 has been identified as a putative receptor for C-peptide (Yosten et al. 2013), with the authors' suggestion that confirmatory experiments are especially important.

However, at the same time non-receptormediated mechanisms for C-peptide biological effect have been proposed. C-peptide has been reported to be internalized in the cytosol and in the nucleus of some cells types (Luppi et al. 2009, Li et al. 2013). Here, direct interaction with intracellular proteins and enzymes affects multiple processes including glycolysis and cell growth (Ishii et al. 2012, Jagerbrink et al. 2009).

\section{C-peptide points to gender differences in glycoregulation throughout life}

Several current approaches are available for the diagnosis of impaired beta cell function (Muniyappa et al. 2008). Among them, the oral glucose tolerance test (oGTT) and the derived equations (insulin sensitivity and insulin secretion indices) are being used in various clinical settings in which the performance of clamps or the minimal model would be impractical. Being relatively simple to implement and not very expensive, oGTT is the most suitable test for epidemiological studies (Stumvoll et al. 2000). Recently, significant influence of the hepatic extraction of insulin (Faerch 2010) and thus use of alternative C-peptide oGTT trajectories and C-peptidederived indices has been discussed and gradually put into practice as more accurate markers of beta cell function compared to insulin trajectories and insulin-derived indices (Vrbikova et al. 2009, Tura et al. 2011, Tura et al. 2012, Včelák et al. 2012, Saisho et al. 2013, Vejrazkova et al. 2015, Lukášová et al. 2015, Vejrazkova et al. 2017, Wildová et al. 2017). Subsequently, several authors, including our research group (Bendlová et al. 2015), have reported sex differences in insulin and C-peptide 
responses to oGTT, indicating that the pathogenesis of diabetes may differ between the genders (Kautzky-Willer et al. 2012, Vistisen et al. 2014, Tura et al. 2018). According to our data based on the long-term monitoring of large cohorts of volunteers with varying degrees of glucose tolerance, the volume of insulin metabolized during the first-pass elimination by the liver seems to decline more markedly in men compared to women, and it turns out that these differences deepen over the course of life (Bendlová et al. 2015, Bendlová et al. 2018).

\section{The methodological contribution of the Institute of Endocrinology}

The Institute of Endocrinology in Prague has been paying much attention to the issue of C-peptide and its metabolic effects since the 1980s. At that time, the diagnostic potential of C-peptide was already evident, but foreign commercial kits to measure its concentrations were unavailable in the then Czechoslovakia. Thanks to the support of the then management of the institute, Prof. Luboslav Stárka and Prof. Karel Vondra, and also thanks to the pragmatism of Dr. Pavel Štolba, a novel radioimmunoassay method (RIA) appropriate for C-peptide measurements began to evolve. As a relatively high amount of human C-peptide was required for its development, the chemical synthesis of a modified human C-peptide - one of the longest peptides synthesized at that time - was successfully implemented and subsequently patented by Dr. Běla Bendlová in cooperation with the Institute of Organic Chemistry and Biochemistry. The synthesized C-peptide was then used for the immunization of guinea pigs. The antiserum with the best association constant $\left(\mathrm{K}_{\mathrm{a}}=1.9 \times 10^{10} \mathrm{l} / \mathrm{mol}\right)$ was selected for the RIA determination of human C-peptide. This methodology has been transferred to commercial production and has been widely used since 1988 (Bendlová et al. 1988, Bendlová 1994a).

Monoclonal antibodies produced using the synthesized C-peptide (Hilgert et al. 1991) have been further used to determine or extract molecules containing C-peptide fragments, i.e. human proinsulin and split proinsulins. The application area here was the diagnosis of pancreatic beta cell tumors, familial hyperproinsulinemia, or studies of insulin and proinsulin secretion under other pathological conditions.

The Institute has also contributed to elucidating the contradictory biological functions of C-peptide. In an effort to identify specific binding sites for C-peptide, membranes of human placenta and erythrocytes were isolated, on which fully functional insulin receptors were detected. However, under the same experimental conditions, no specific C-peptide binding sites were demonstrated on these cell membranes. It is thus possible to assume that the binding of C-peptide to receptors requires completely different conditions or that $\mathrm{C}$-peptide acts in tissues by another mechanism (Bendlová 1994a, Bendlová 1994b).

The scientific team of the Institute of Endocrinology was also behind the observation that the increase of 24-h urine excretion of C-peptide was predictive for remission of newly diagnosed T1DM after the therapy with somatostatin (Vondra et al. 2004). Attention deserves also finding of coexistence and tight association between thyroid and Langerhans islets autoimmunity, which was described in young adults with T1DM. During long-term follow-up, faster cessation of endogenous C-peptide secretion was associated with thyroid peroxidase and thyroglobulin antibodies positivity (Vondra et al. 2005).

\section{Conclusion and perspectives}

In summary, there is much evidence that C-peptide is a biologically active molecule that serves as an endogenous antioxidant, preventing, in adjunction with insulin, hyperglycemia-induced microvascular dysfunction. It is also apparent that C-peptide has therapeutic potential for the treatment of vascular and nervous damage caused by T1DM or late T2DM (Yosten et al. 2014). Thus far, its replacement in T1DM patients has yielded positive results (Johansson et al. 2000, Wahren et al. 2012), though the short half-life of C-peptide has proven to be a limiting complication in the conduction of large human trials. However, chemically modified long-acting C-peptide molecules have already been developed (Wahren et al. 2016, Zashikhina et al. 2019). If they show long-term safety and their effects translate to improved outcomes for diabetic patients, the introduction of C-peptide into clinical practice in the therapy of T1DM and late T2DM-associated complications would be a very important and desirable achievement.

Once C-peptide was shown to be a biologically active molecule, the search for its receptor has led to significant progress in ascertaining the physiological relevance of the peptide. Most intracellular signaling cascades observed following exposure to C-peptide have 
been associated with the activation of a GPR, although the binding dynamics indicates that the peptide may bind to a complex of proteins rather than to a single receptor (Pramanik et al. 2001). Furthermore, some studies have suggested that C-peptide exerts its action through alternative non-receptor-mediated mechanisms.

As C-peptide, unlike insulin, escapes hepatic extraction and has a much longer half-life in the circulation, it has widely been used as a measure of insulin secretion to assess beta cell function. Bypassing clearance by the liver also allows a much wider use of C-peptide in human physiology research, such as evaluations of hepatic insulin extraction changes throughout life or during the development of some pathological condition. The diagnostic potential of C-peptide and especially C-peptide oGTT-derived indices may provide a deeper understanding of the pathophysiology of not only type 1 and type 2 diabetes mellitus, but also possibly other diabetes-associated pathological conditions such as non-alcoholic fatty liver disease.

\section{Conflict of Interest}

There is no conflict of interest.

\section{Acknowledgements}

Supported by Ministry of Health of the Czech Republic, grant NU20-01-00308 and RVO 00023761.

\section{References}

BENDLOVÁ B: Synthesis of human C-peptide, development of RIA assay and its further use for research purposes. (In Czech) Candidate dissertation, Academy of Sciences of the Czech Republic, Prague, 1994a, pp 1-106.

BENDLOVÁ B: Human C-peptide. The importance of its determination and the question of its biological function. (In Czech) Chemické listy 88: 51-58, 1994b.

BENDLOVÁ B, LEBL M, ŠTOLBA P: Synthesis of modified human C-peptide and its fragments. Coll Czech Chem Commun 53: 2637-2644, 1988. https://doi.org/10.1135/cccc19882637

BENDLOVÁ B, VEJRAŽKOVÁ D, LUKÁŠOVÁ P, BRADNOVÁ B, VACÍNOVÁ G, VČELÁK J, ŠEDA O, VAŇKOVÁ M: Changes in glucose tolerance and influence of genetic background - semilongitudinal study. (In Czech) DMEV 18: 35-36, 2015.

BENDLOVÁ B, VEJRAŽKOVÁ D, LUKÁŠOVÁ P, ŠEDOVÁ L, ŠEDA O, VČELÁK J, VAŇKOVÁ M: Shape of glycemic curves during OGTT: relationship to glucose tolerance and genetic background. (In Czech) DMEV 21: 18, 2018.

BHATT MP, LIM YC, HWANG J, NA S, KIM YM, HA KS: C-peptide prevents hyperglycemia-induced endothelial apoptosis through inhibition of reactive oxygen species-mediated transglutaminase 2 activation. Diabetes 62: 243-253, 2013a. https://doi.org/10.2337/db12-0293

BHATT MP, LIM YC, KIM YM, HA KS: C-peptide activates AMPK $\alpha$ and prevents ROS-mediated mitochondrial fission and endothelial apoptosis in diabetes. Diabetes 62: 3851-3862, 2013b. https://doi.org/10.2337/db130039

CABRERA DE LEÓN A, OLIVA GARCÍA JG, MARCELINO RODRÍGUEZ I, ALMEIDA GONZÁLEZ D, ALEMÁN SÁNCHEZ JJ, BRITO DÍAZ B, DOMÍNGUEZ COELLO S, BERTOMEU MARTÍNEZ V, AGUIRRE JAIME A, RODRÍGUEZ PÉREZ MDEL C: C-peptide as a risk factor of coronary artery disease in the general population. Diab Vasc Dis Res 12: 199-207, 2015. https://doi.org/10.1177/1479164114564900

EKBERG K, BRISMAR T, JOHANSSON BL, LINDSTRÖM P, JUNTTI-BERGGREN L, NORRBY A, BERNE C, ARNQVIST HJ, BOLINDER J, WAHREN J: C-Peptide replacement therapy and sensory nerve function in type 1 diabetic neuropathy. Diabetes Care 30: 71-76, 2007. https://doi.org/10.2337/dc06-1274

FAERCH K, BRØNS C, ALIBEGOVIC AC, VAAG A: The disposition index: adjustment for peripheral vs. hepatic insulin sensitivity? J Physiol 588: 759-764, 2010. https://doi.org/10.1113/jphysiol.2009.184028

FIORINA P, FOLLI F, ZERBINI G, MAFFI P, GREMIZZI C, DI CARLO V, SOCCI C, BERTUZZI F, KASHGARIAN M, SECCHI A: Islet transplantation is associated with improvement of renal function among uremic patients with type I diabetes mellitus and kidney transplants. J Am Soc Nephrol 14: 2150-2158, 2003. 
HAIDET J, CIFARELLI V, TRUCCO M, LUPPI P: C-peptide reduces pro-inflammatory cytokine secretion in LPS-stimulated U937 monocytes in condition of hyperglycemia. Inflamm Res 61: 27-35, 2012. https://doi.org/10.1007/s00011-011-0384-8

HENRIKSSON M, PRAMANIK A, SHAFQAT J, ZHONG Z, TALLY M, EKBERG K, WAHREN J, RIGLER R, JOHANSSON J, JÖRNVALL H: Specific binding of proinsulin C-peptide to intact and to detergentsolubilized human skin fibroblasts. Biochem Biophys Res Commun 280: 423-427, 2001. https://doi.org/10.1006/bbrc.2000.4135

HILGERT I, ŠTOLBA P, KRIŠTOFOVÁ H, ŠTEFANOVÁ I, BENDLOVÁ B, LEBL M, HOŘEJŠÍ V: A monoclonal antibody applicable for determination of C-peptide of human proinsulin by RIA. Hybridoma 10: 379-386, 1991. https://doi.org/10.1089/hyb.1991.10.379

ISHII T, FUKANO K, SHIMADA K, KAMIKAWA A, OKAMATSU-OGURA Y, TERAO A, YOSHIDA T, SAITO M, KIMURA K: Proinsulin C-peptide activates $\alpha$-enolase: implications for C-peptide--cell membrane interaction. J Biochem 152: 53-62, 2012. https://doi.org/10.1093/jb/mvs052

JÄGERBRINK T, LINDAHL E, SHAFQAT J, JÖRNVALL H: Proinsulin C-peptide interaction with protein tyrosine phosphatase 1B demonstrated with a labeling reaction. Biochem Biophys Res Commun 387: 31-35, 2009. https://doi.org/10.1016/j.bbrc.2009.06.074

JOHANSSON BL, BORG K, FERNQVIST-FORBES E, KERNELL A, ODERGREN T, WAHREN J: Beneficial effects of C-peptide on incipient nephropathy and neuropathy in patients with type 1 diabetes mellitus. Diabet Med 17: 181-189, 2000. https://doi.org/10.1046/j.1464-5491.2000.00274.x

KAUTZKY-WILLER A, BRAZZALE AR, MORO E, VRBÍKOVÁ J, BENDLOVA B, SBRIGNADELLO S, TURA A, PACINI G: Influence of increasing BMI on insulin sensitivity and secretion in normotolerant men and women of a wide age span. Obesity (Silver Spring) 20: 1966-1973, 2012. https://doi.org/10.1038/oby.2011.384

KITAMURA T, KIMURA K, JUNG BD, MAKONDO K, OKAMOTO S, CAÑAS X, SAKANE N, YOSHIDA T, SAITO M: Proinsulin C-peptide rapidly stimulates mitogen-activated protein kinases in Swiss 3T3 fibroblasts: requirement of protein kinase $\mathrm{C}$, phosphoinositide 3-kinase and pertussis toxin-sensitive G-protein. Biochem $\mathrm{J}$ 355: 123-129, 2001. https://doi.org/10.1042/bj3550123

LACHIN JM, MCGEE P, PALMER JP, DCCT/EDIC RESEARCH GROUP: Impact of C-peptide preservation on metabolic and clinical outcomes in the Diabetes Control and Complications Trial. Diabetes 63: 739-748, 2014. https://doi.org/10.2337/db13-0881

LI Y, ZHAO M, LI B, QI J: Dynamic localization and functional implications of C-peptide might for suppression of iNOS in high glucose-stimulated rat mesangial cells. Mol Cell Endocrinol 381: 255-260, 2013. https://doi.org/10.1016/j.mce.2013.08.007

LUKÁŠOVÁ P, VAŇKOVÁ M, VČELÁK J, VEJRAŽKOVÁ D, BRADNOVÁ O, STANICKÁ S, HAINER V, BENDLOVÁ B: Fat mass and obesity associated gene variants are associated with increased growth hormone levels and affect glucose and lipid metabolism in lean women. Physiol Res 64 (Suppl 2): S177-S185, 2015. https://doi.org/10.33549/physiolres.933088

LUPPI P, GENG X, CIFARELLI V, DRAIN P, TRUCCO M: C-peptide is internalised in human endothelial and vascular smooth muscle cells via early endosomes. Diabetologia 52: 2218-2228, 2009. https://doi.org/10.1007/s00125-009-1476-7

LUPPI P, DRAIN P: C-peptide antioxidant adaptive pathways in $\beta$ cells and diabetes. J Intern Med 281: 7-24, 2017. https://doi.org/10.1111/joim.12522

MUNIYAPPA R, LEE S, CHEN H, QUON MJ: Current approaches for assessing insulin sensitivity and resistance in vivo: advantages, limitations, and appropriate usage. Am J Physiol Endocrinol Metab 294: E15-E26, 2008. https://doi.org/10.1152/ajpendo.00645.2007

NAVARRO X, SUTHERLAND DE, KENNEDY WR: Long-term effects of pancreatic transplantation on diabetic neuropathy. Ann Neurol 42: 727-736, 1997. https://doi.org/10.1002/ana.410420509

PRAMANIK A, EKBERG K, ZHONG Z, SHAFQAT J, HENRIKSSON M, JANSSON O, TIBELL A, TALLY M, WAHREN J, JÖRNVALL H, RIGLER R, JOHANSSON J: C-peptide binding to human cell membranes: importance of Glu27. Biochem Biophys Res Commun 284: 94-98, 2001. https://doi.org/10.1006/bbrc.2001.4917 
RICHARDS JP, YOSTEN GL, KOLAR GR, JONES CW, STEPHENSON AH, ELLSWORTH ML, SPRAGUE RS: Low O2-induced ATP release from erythrocytes of humans with type 2 diabetes is restored by physiological ratios of C-peptide and insulin. Am J Physiol Regul Integr Comp Physiol 307: R862-R868, 2014. https://doi.org/10.1152/ajpregu.00206.2014

RICHARDS JP, BOWLES EA, GORDON WR, ELLSWORTH ML, STEPHENSON AH, SPRAGUE RS: Mechanisms of C-peptide-mediated rescue of low O2-induced ATP release from erythrocytes of humans with type 2 diabetes. Am J Physiol Regul Integr Comp Physiol 308: R411-R418, 2015. https://doi.org/10.1152/ajpregu.00420.2014

SAISHO Y, KOU K, TANAKA K, ABE T, SHIMADA A, KAWAI T, ITOH H: Postprandial serum C-peptide to plasma glucose ratio predicts future insulin therapy in Japanese patients with type 2 diabetes. Acta Diabetologia 50: 987-988, 2013. https://doi.org/10.1007/s00592-012-0441-y

STUMVOLL M, MITRAKOU A, PIMENTA W, JENSSEN T, YKI-JÄRVINEN H, VAN HAEFTEN T, HÄRING H, FRITSCHE A, GERICH J: Use of the oral glucose tolerance test to assess insulin release and insulin sensitivity. Diabetes Care 23: 295-301, 2000. https://doi.org/10.2337/diacare.23.3.295

TURA A, MORBIDUCCI U, SBRIGNADELLO S, WINHOFER Y, PACINI G, KAUTZKY-WILLER A: Shape of glucose, insulin, C-peptide curves during a 3-h oral glucose tolerance test: any relationship with the degree of glucose tolerance? Am J Physiol Regul Integr Comp Physiol 300: R941-R948, 2011. https://doi.org/10.1152/ajpregu.00650.2010

TURA A, PACINI G, KAUTZKY-WILLER A, GASTALDELLI A, DEFRONZO RA, FERRANNINI E, MARI A: Estimation of prehepatic insulin secretion: comparison between standardized C-peptide and insulin kinetic models. Metabolism 61: 434-443, 2012. https://doi.org/10.1016/j.metabol.2011.08.001

TURA A, PACINI G, MORO E, VRBÍKOVÁ J, BENDLOVÁ B, KAUTZKY-WILLER A: Sex- and age-related differences of metabolic parameters in impaired glucose metabolism and type 2 diabetes compared to normal glucose tolerance. Diabetes Res Clin Pract 146: 67-75, 2018. https://doi.org/10.1016/j.diabres.2018.09.019

VČELÁK J, VEJRAŽKOVÁ D, VAŇKOVÁ M, LUKÁŠOVÁ P, BRADNOVÁ O, HÁLKOVÁ T, BEŠŤÁK J, ANDĚLOVÁ K, KVASNIČKOVÁ H, HOSKOVCOVÁ P, VONDRA K, VRBÍKOVÁ J, BENDLOVÁ B: T2D risk haplotypes of the TCF7L2 gene in the Czech population sample: the association with free fatty acids composition. Physiol Res 61: 229-240, 2012. https://doi.org/10.33549/physiolres.932272

VEJRAZKOVA D, LUKASOVA P, VANKOVA M, BRADNOVA O, VACINOVA G, VCELAK J, CIRMANOVA V, ANDELOVA K, KREJCI H, BENDLOVA B: Gestational diabetes - metabolic risks of adult women with respect to birth weight. Physiol Res 64 (Suppl 2): S135-S145, 2015. https://doi.org/10.33549/physiolres.933089

VEJRAZKOVA D, LISCHKOVA O, VANKOVA M, STANICKA S, VRBIKOVA J, LUKASOVA P, VCELAK J, VACINOVA G, BENDLOVA B: Distinct response of fat and gastrointestinal tissue to glucose in gestational diabetes mellitus and polycystic ovary syndrome. Physiol Res 66: 283-292, 2017. https://doi.org/10.33549/physiolres.933366

VISTISEN D, WITTE DR, TABÁK AG, BRUNNER EJ, KIVIMÄKI M, FÆRCH K: Sex differences in glucose and insulin trajectories prior to diabetes diagnosis: the Whitehall II study. Acta Diabetol 51: 315-319, 2014. https://doi.org/10.1007/s00592-012-0429-7

VONDRA K, VOBORSKÁ M, KVAPIL M, WEBER P, DVORÁKOVÁ H, STANICKÁ S, ZAMRAZIL V: Somatostatin: beneficial effects on remission in young adult patients with newly diagnosed diabetes mellitus type 1. Physiol Res 53: 115-117, 2004.

VONDRA K, VRBÍKOVÁ J, BENDLOVÁ B, DVORAKOVA K, STERZL I, VONDROVA M: Differences in type I diabetes mellitus of young adults with and without thyroid autoimmunity. Exp Clin Endocrinol Diabetes 113: 404-408, 2005. https://doi.org/10.1055/s-2005-865769

VRBIKOVA J, BENDLOVA B, VANKOVA M, DVORAKOVA K, GRIMMICHOVA T, VONDRA K, PACINI G: Beta cell function and insulin sensitivity in women with polycystic ovary syndrome: influence of the family history of type 2 diabetes mellitus. Gynecol Endocrinol 25: 597-602, 2009. https://doi.org/10.1080/09513590902972133 
WAHREN J: C-peptide and the pathophysiology of microvascular complications of diabetes. J Intern Med 281: 3-6, 2017. https://doi.org/10.1111/joim.12541

WAHREN J, KALLAS A, SIMA AA: The clinical potential of C-peptide replacement in type 1 diabetes. Diabetes 61: 761-772, 2012. https://doi.org/10.2337/db11-1423

WAHREN J, FOYT H, DANIELS M, AREZZO JC: Long-acting C-peptide and neuropathy in type 1 diabetes: a 12-month clinical trial. Diabetes Care 39: 596-602, 2016. https://doi.org/10.2337/dc15-2068

WANG L, LIN P, MA A, ZHENG H, WANG K, LI W, WANG C, ZHAO R, LIANG K, LIU F, HOU X, SONG J, LU Y, ZHU P, SUN Y, CHEN L: C-peptide is independently associated with an increased risk of coronary artery disease in T2DM subjects: a cross-sectional study. PLoS One 10: e0127112, 2015. https://doi.org/10.1371/journal.pone.0127112

WILDOVÁ E, KRAML P, POTOČKOVÁ J, DLOUHÝ P, ANDĚL M: The assessment of the serum C-peptide and plasma glucose levels by orally administered whey proteins in type 2 diabetes mellitus. Physiol Res 66: 993-999, 2017. https://doi.org/10.33549/physiolres.933477

YOSTEN GL, KOLAR GR: The physiology of proinsulin C-peptide: unanswered questions and a proposed model. Physiology (Bethesda) 30: 327-332, 2015. https://doi.org/10.1152/physiol.00008.2015

YOSTEN GL, KOLAR GR, REDLINGER LJ, SAMSON WK: Evidence for an interaction between proinsulin C-peptide and GPR146. J Endocrinol 218: B1-B8, 2013. https://doi.org/10.1530/JOE-13-0203

YOSTEN GL, MARIC-BILKAN C, LUPPI P, WAHREN J: Physiological effects and therapeutic potential of proinsulin C-peptide. Am J Physiol Endocrinol Metab 307: E955-E968, 2014. https://doi.org/10.1152/ajpendo.00130.2014

ZASHIKHINA N, SHAROYKO V, ANTIPCHIK M, TARASENKO I, ANUFRIKOV Y, LAVRENTIEVA A, TENNIKOVA T, KORZHIKOVA-VLAKH E: Novel formulations of C-peptide with long-acting therapeutic potential for treatment of diabetic complications. Pharmaceutics 11: E27, 2019. https://doi.org/10.3390/pharmaceutics11010027

ZHONG Z, KOTOVA O, DAVIDESCU A, EHRÉN I, EKBERG K, JÖRNVALL H, WAHREN J, CHIBALIN AV: C-peptide stimulates $\mathrm{Na}+, \mathrm{K}+$-ATPase via activation of ERK1/2 MAP kinases in human renal tubular cells. Cell Mol Life Sci 61: 2782-2790, 2004. https://doi.org/10.1007/s00018-004-4258-X

ZHONG Z, DAVIDESCU A, EHRÉN I, EKBERG K, JÖRNVALL H, WAHREN J, CHIBALIN AV: C-peptide stimulates ERK1/2 and JNK MAP kinases via activation of protein kinase $\mathrm{C}$ in human renal tubular cells. Diabetologia 48: 187-197, 2005. https://doi.org/10.1007/s00125-004-1602-5 